\title{
The in situ Analysis of Interfacial Reactions between Electrode and Organic Electrolytes III. The Reduction of Electrolytes at Graphite Electrode
}

\author{
Ken-ichi MORIGAKI*, Takabumi FUJII and Akira OHTA
}

Received December 18, 1997 ; Accepted August 19, 1998

\begin{abstract}
We applied the in situ FTIR and AFM measurements for the analysis of interfacial phenomena at graphite electrode in organic electrolytes. The electrolyte solutions used were EC+DEC and EC+EMC each containing $1 \mathrm{~mol} / \mathrm{dm}^{3} \mathrm{LiPF}_{6}$. The different reduction mechanism of solvents was observed in EC+DEC and in EC+EMC. It was confirmed the morphological changes of graphite particles were occurred at $1.0 \mathrm{~V} \mathrm{vs.} \mathrm{Li}^{-} \mathrm{Li}^{+}$in the first cathodic polarization by the AFM observation. A larger expansion of graphite particles was observed in EC+DEC than in EC+EMC, and this expansion of graphite would be related to the decomposition of ternary solvated lithium graphite-intercalation compounds.
\end{abstract}

\section{INTRODUCTION}

Many groups are studying and investigating about the cathode materials for rechargeable lithium-ion batteries such as $\mathrm{LiCoO}_{2}, \mathrm{LiNiO}_{2}$ and $\mathrm{LiMn}_{2} \mathrm{O}_{4}$, and the anode materials such as graphites, cokes and amorphous carbons. But a few groups studies about organic electrolytes of rechargeable lithium-ion batteries ${ }^{1-10)}$. The interfacial reaction between electrode and electrolyte is the one of the most important factors which influence the battery performances of this battery system. Difficulties of the analysis of the interfacial reactions of lithium ion batteries are that the amount of these products is very small and these products generally form very thin layer and react with $\mathrm{H}_{2} \mathrm{O}, \mathrm{CO}_{2}$ and $\mathrm{O}_{2}$, which are atmospheric components. Since these reaction products are very instable, it is necessary to conduct in situ analysis and experiments in the study of lithium-ion batteries.

Fourier Transform Infrared(FTIR) spectroscopy is one of the useful methods for in situ analysis of the interfacial reactions on the electrodes in organic electrolytes. Aurbach et. al., investigated the surface reactions of lithium and graphite electrodes in many organic electrolytes by in situ FTIR $^{1-8)}$

Atomic Force Microscopy(AFM) is also regarded as the useful method for in situ analysis. We have demonstrated Technology Laboratory, Matsushita Battery Industrial Co.,LTD., (1, Matsushita-cho, Moriguchi, Osaka 5708511, Japan)

Key Words: FTIR, AFM, organic electrolyte, graphite electrode
AFM observation is a useful method for in situ analysis of lithium surface and for the study of deposition in organic electrolytes ${ }^{11-13)}$. Yamaguchi et. al., studied the morphological changes of graphite electrodes during discharging by electrochemical $\mathrm{AFM}^{14,15)}$, and Ogumi et. al., investigated the surface morphology of graphite electrodes with the polarization by electrochemical STM $^{16,17)}$.

Aurbach reported that ethylmethyl carbonate(EMC) was the promising solvent for rechargeable lithium-ion batteries $^{8)}$, because graphite electrodes had long cycle performances with high reversible capacity in the electrolyte using EMC. On the other hand, diethyl carbonate(DEC) was not the suitable solvent ${ }^{5-7}$; Lithium and graphite electrodes can not be passivated in DEC solutions, because the solvent reduction products are soluble in this solvent. And the performance of lithium or graphite electrode show low cycling efficiency in the solution containing DEC, such as ethylene carbonate(EC) $+D E C$ solution.

In this study we investigate the surface chemistry of in $\mathrm{LiPF}_{6} / \mathrm{EC}$ electrolytes, using DEC or EMC as the cosolvent, and compare the effect of co-solvent on the interfacial reactions at graphite electrode. We examined the in situ FTIR spectroscopy for the analysis of interfacial reactions and the in situ AFM observation for the analysis of the surface morphology of graphite electrodes during lithium intercalation-deintercalation. 


\section{EXPERIMENTAL}

EC, DEC, and EMC(Mitsubishi Chemical) and $\mathrm{LiPF}_{6}$ (Stella Chemifa) were used as received. The electrolytes used were $\mathrm{EC}+\mathrm{DEC}(1: 1$ by volume) and $\mathrm{EC}+\mathrm{EMC}(1: 1$ by volume) each containing $1 \mathrm{~mol} / \mathrm{dm}^{3} \mathrm{LiPF}_{6}$, and below $50 \mathrm{ppm}$ of water. We examined the two methods of in situ FTIR spectroscopy for the analysis of interfacial reactions at graphite electrodes using a Mattson RS-2 spectrometer ${ }^{13)}$. One is Infrared Reflection Absorption Spectroscopy(IRAS) and another is Double Modulation FTIR (DMFTIR) spectroscopy ${ }^{18)}$. The IRAS spectroscopy using p-polarized IR beam was performed to investigate the reactions of electrolytes at graphite electrodes. The DMFTIR spectroscopy using p-polarized and s-polarized IR beams modulated by photoelastic modulator(PEM-90, Hinds) was performed to investigate the interfacial reactions at graphite electrodes. The DMFTIR spectra data were sampled by the realtime sampling electronics (Mattson) the difference between p-polarized data and spolarized data as a sample spectrum, and the sum of $p$ - and s-polarized data as a reference spectrum. The center frequency of DMFTIR was set at $1200 \mathrm{~cm}^{-1}$ in present study. 100 scans were conducted in each measurement, and the resolution was $2 \mathrm{~cm}^{-1}$. The test cell for in situ FTIR spectroscopy was performed as same as reported before ${ }^{13}$. The in situ AFM measurement was performed using TMX1000 (Topometrix) as same as reported in our previous papers ${ }^{11,12)}$. A composite graphite working electrode was prepared by a coating of graphite paste on a $\mathrm{Cu}$ rode $(\phi$ $8 \mathrm{~mm}$ ), and it was dried at $110^{\circ} \mathrm{C}$ under vacuum, and polished with soft clothes. The graphite paste was consisted of Meso Carbon Micro Beads(MCMB, from Osaka gas, mean grain size; $4 \mu \mathrm{m}$ ), styrene-butadiene rubber as binder, carboxylmetyl cellulose and water. Lithium was used as a counter electrode and a reference electrode in test cells.

The polarizations with in situ measurements were performed by a potentio/galvanostat system HA-301/HB104(Hokuto denko). The measurements of FTIR and AFM were performed after the current of the working electrode was decreased under $20 \mu \mathrm{A}$. All experiments were performed at room temperature.

\section{RESULTS and DISCUSSION}

Figure 1 compares DMFTIR spectra of the mixed solvent(EC+DEC, la) and electrolyte $\left(1 \mathrm{~mol} / \mathrm{dm}^{3} \mathrm{LiPF}_{6} /\right.$ EC+DEC, 1b) on graphite electrodes at OCV state, and the difference in these spectra shows as a subtractive spectrum (1c). The major peaks due to the stretching vibration of carbonyl groups $\left(v_{C}=0\right)$ were observed at $1800(E C)$, 1772 (EC) and $1736 \mathrm{~cm}^{-1}(\mathrm{DEC})$ in both spectra (la and $\mathrm{lb}$ ).
The DMFTIR and IRAS spectra of some solvents were measured at the same condition, and the assignments of each peaks of solvents are shown in Table 1. As shown in 1c, increasing new peaks by dissolution of $\mathrm{LiPF}_{6}$ were observed at $1759,1680 \mathrm{~cm}^{-1}\left(\mathrm{vC}_{\mathrm{C}}=0\right), 1405,1298,1194$, $1086,1045 \mathrm{~cm}^{-1}\left(\mathrm{UC}_{\mathrm{C}-0}\right)$ and $841 \mathrm{~cm}^{-1}$. We confirmed the changes of spectra related to the solvation of lithium ion were observed increasing peaks around 1190 and around

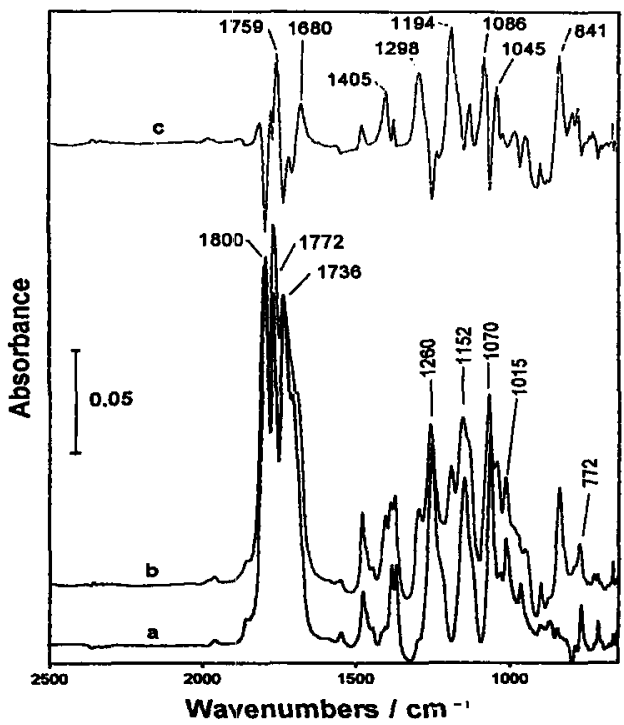

Fig. 1 Comparison of DMFTIR spectra of solvent and electrolyte at graphite electrodes at OCV. a; solvent (EC+DEC),b; electrolyte(1 mol/dm ${ }^{3}$ LiPF $\left.6 / E C+D E C\right)$, c; subtractive spectrum.

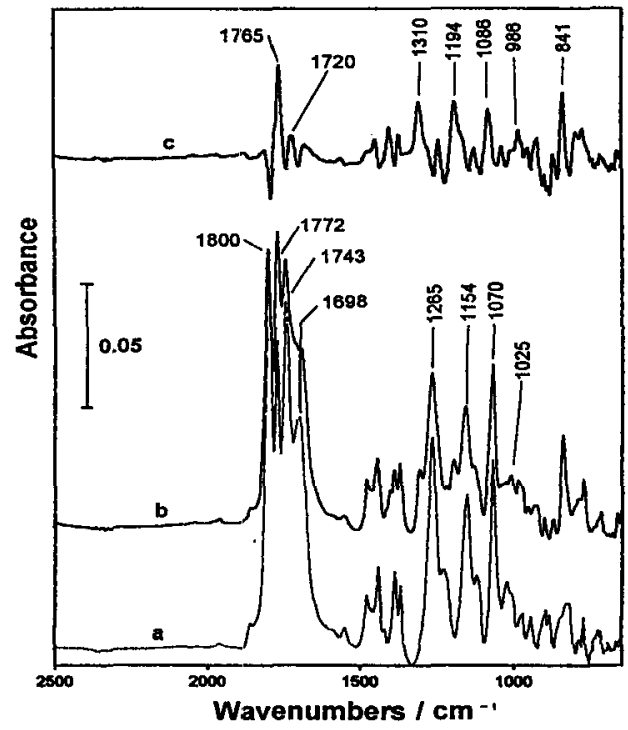

Fig. 2 Comparison of DMFTIR spectra of solvent and electrolyte at graphite electrodes at OCV. a; solvent (EC+EMC), b; electrolyte(1mol/m' LIPF\&/EC+EMC), c; subtractive spectrum. 
Table 1 Assignment of peaks in DMFTIR and IRAS spectra of solvents

\begin{tabular}{|c|c|c|c|c|c|}
\hline & $\begin{array}{c}E C \\
D M \text { (IRAS) }\end{array}$ & $\begin{array}{c}\text { DEC } \\
\text { DM (IRAS) }\end{array}$ & $\begin{array}{c}\text { EMC } \\
\text { DM (IRAS) }\end{array}$ & $\begin{array}{c}\text { DMC } \\
\text { DM (IRAS) }\end{array}$ & $\begin{array}{l}\text { DME } \\
\text { DM (IRAS) }\end{array}$ \\
\hline$\vee C=0$ & $\begin{array}{l}1800(1792) \\
1772(1765)\end{array}$ & $1741(1724)$ & $1746(1726)$ & $1752(1728)$ & $-(-)$ \\
\hline $\begin{array}{l}\delta \mathrm{CH}, \mathrm{CH} 3 \\
v \mathrm{C}-\mathrm{O}-\mathrm{C} \\
v \mathrm{C}-\mathrm{O}\end{array}$ & $\begin{array}{l}1480(1480) \\
1388(1386) \\
1230 \\
1158(1127) \\
1070(1040)\end{array}$ & $\begin{array}{l}1467(1467) \\
1373(1370) \\
1251 \\
1142(1183) \\
1090(1086)\end{array}$ & $\begin{array}{l}1441(1438) \\
1368(1367) \\
1258 \\
1140(1164) \\
1113(1112) \\
1088(1087)\end{array}$ & $\begin{array}{l}1452(1446) \\
1432(1430) \\
1271 \\
1135(1178) \\
1093(1137)\end{array}$ & $\begin{array}{l}1452(1452) \\
1365(1365) \\
1245 \\
1190(1190) \\
1107(1110) \\
1058(1083)\end{array}$ \\
\hline \multirow[t]{2}{*}{$\vee \mathrm{C}-\mathrm{C}$} & 1029 & $1017(960)$ & 1008 & $-(\rightarrow)$ & $1023(1024)$ \\
\hline & $\begin{array}{l}990(950) \\
970(910)\end{array}$ & (897) & $\begin{array}{l}970(983) \\
932(920)\end{array}$ & $968(940)$ & $\begin{array}{l}980(980) \\
934(935)\end{array}$ \\
\hline $8 \mathrm{CO} 3$ & (872) & $\begin{array}{r}853(841) \\
(820)\end{array}$ & $876(868)$ & $888(897)$ & $-(\rightarrow)$ \\
\hline
\end{tabular}

DMC: Dimethyl carbonate, DME: Dimethoxy ethane.

$800 \mathrm{~cm}^{-1}$ and decreasing peaks around 1120 and from 1000 to $860 \mathrm{~cm}^{-1}$ in EC+DEC system. Therefore the peak at $1194 \mathrm{~cm}^{-1}$ was ascribed to the change due to the solvation, and the peaks at $1680,1405,1298$ and $1086 \mathrm{~cm}^{-1}$ were consistent with those in previous FTIR studies ${ }^{3,4)}$ of lithium alkylcarbonates $\left(\mathrm{ROCO}_{2} \mathrm{Li}\right)$, which have the peaks at $1680-1640\left(\mathrm{v}_{\mathrm{C}=0}\right), 1450-1400\left(\delta_{\mathrm{cH}}, \mathrm{CH}_{3}\right), 1350-1300(\mathrm{v}$ $\mathrm{C}=0), 1100\left(v_{\mathrm{C}-0}\right), 830-820 \mathrm{~cm}^{-1}\left(\delta_{\mathrm{OCO}_{2}}\right)$. Aurbach reported that the FTIR spectra in LiPF $_{6}$ solution have pronounced 1030 and $850 \mathrm{~cm}^{-1}$ peaks which are assigned to UP-o and up. F, respectively ${ }^{5-7)}$. And XPS studies revealed that the salt reduction products are $\mathrm{LiF}$ and $\mathrm{Li}_{x} \mathrm{PF}_{y}$ or $\mathrm{Lix}_{\mathrm{x}} \mathrm{PF}_{\mathrm{y}} \mathrm{O}_{z}{ }^{7,19,20)}$. Therefore, we think that the peak at $841 \mathrm{~cm}^{-1}$ is probably superimposed with the $\delta_{\mathrm{OCO}_{2}}$ peak of $\mathrm{ROCO}_{2} \mathrm{Li}$ and the $v$ P-F peak of decomposition product of $\mathrm{LiPF}_{6}$. We think the other peaks at 1759 and $1045 \mathrm{~cm}^{-1}$ will be ascribed to another $\mathrm{ROCO}_{2} \mathrm{Li}$, which is also the decomposition product of $\mathrm{EC}$ or $\mathrm{DEC}$.

A comparison of DMFTIR spectra of EC+EMC(a) and $\mathrm{LiPF}_{6} / \mathrm{EC}+\mathrm{EMC}(\mathrm{b})$, as the same in Fig. 1 , is shown in Fig.2. The peaks at 1800 and $1772 \mathrm{~cm}^{-1}$ were assigned to $\mathrm{EC}$, the peak at $1743 \mathrm{~cm}^{-1}$ was assigned to EMC, and the peak at $1698 \mathrm{~cm}^{-1}$ would be assigned to alkylcarbonate, respectively. As shown in $2 \mathrm{c}$, increasing peaks by dissolution of $\mathrm{LiPF}_{6}$ were observed at $1765,1720\left(\mathrm{vC}_{\mathrm{C}}=\mathrm{O}\right)$, $1310,1194,1086,986 \mathrm{~cm}^{-1}$ (Uc-o, Uc-C) and $841 \mathrm{~cm}^{-1}$. We think these peaks are also ascribed to decomposition products of solvents. The different increasing peaks were observed at $1720,1310,986 \mathrm{~cm}^{-1}$, which seem to be ascribed to reduction product of EMC.

Figure 3 shows typical cyclic voltammograms at graphite electrodes in $1 \mathrm{~mol} / \mathrm{dm}^{3} \mathrm{LiPF}_{6} / \mathrm{EC}+\mathrm{DEC}$ and in 1 $\mathrm{mol} / \mathrm{dm}^{3} \mathrm{LiPF}_{6} / \mathrm{EC}+\mathrm{EMC}$, using a test cell for AFM measurement. At the first cathodic scan(from OCV to OV vs. $\left.\mathrm{Li} / \mathrm{Li}^{\dagger}\right)$, the cathodic current was observed below about
$2.6 \mathrm{~V}$ and showed broad peaks around $0.7-0.6 \mathrm{~V}$. But at the second and third scans(from $1 \mathrm{~V}$ to $0 \mathrm{~V}$ ) the cathodic current showed only one peak at around $0 \mathrm{~V}$, which was corresponding to lithium intercalation. These results revealed the irreversible cathodic reaction existed at only the first polarization. The peak due to lithium intercalationdeintercalation decreased with cycles, and the reduction of this peak was much more in EC+DEC than that of in EC+EMC. Consequently, it is expected the rechargeability of graphite in EC+EMC are superior to those in EC+DEC. The difference of electrochemical behavior may be caused by the interfacial reaction, thus we examined the morphological changes of graphite electrodes in the polarization by in situ AFM observation.

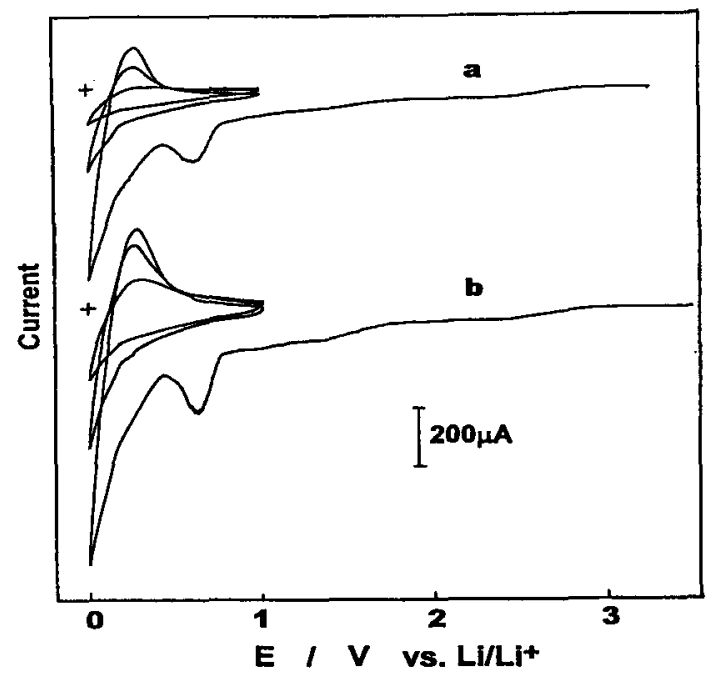

Fig. 3 Cyclic voltammograms of $1 \mathrm{~mol}^{\mathrm{d} \mathrm{dm}^{3}}$ LIPF $/$ EC+DEC(a) and EC+EMC(b) at graphite electrodes in a test cell for AFM measurement. scan rate; $1 \mathrm{mV} / \mathrm{s}$. 
Figure 4 shows typical AFM images $(20 \times 20 \mu \mathrm{m}$ area $)$ of graphite electrode in $1 \mathrm{~mol} / \mathrm{dm}^{3} \mathrm{LiPF}_{6} / \mathrm{EC}+\mathrm{DEC}$ and in $\mathrm{LiPF}_{6} / \mathrm{EC}+\mathrm{EMC}$ at various conditions. In the present work AFM images were treated by a leveling process and a modification of the irregular traces in the scanning. Several small particles of MCMB were observed at initial state(OCV) and they enlarged about $0.7 \mu \mathrm{m}$ in height at $0.05 \mathrm{~V}$ vs. $\mathrm{Li} / \mathrm{Li}^{+}$in $\mathrm{EC}+\mathrm{DEC}$. On the other hand, the expansion of MCMB particles was about $0.4 \mu \mathrm{m}$ in height at $0.05 \mathrm{~V}$ in $\mathrm{EC}+\mathrm{EMC}$, and it was smaller than that of in EC+DEC.

Figure 5 shows AFM images $(5 \times 5 \mu \mathrm{m}$ area) of graphite electrode at the first cathodic polarization and the anodic polarization to $1.0 \mathrm{~V}$ vs. $\mathrm{Li} / \mathrm{Li}^{+}$. The AFM image at $\mathrm{OCV}$ showed that MCMB particle size was in the range of 0.5 $1.2 \mu \mathrm{m}$. Although the result of cyclic voltammogram showed the irreversible reaction existed at $0.6-0.7 \mathrm{~V}$ and the reaction of lithium intercalation occurred below $0.4 \mathrm{~V}$, $\mathrm{AFM}$ images at $1.5 \mathrm{~V}(5 \mathrm{~b})$ and $1.0 \mathrm{~V}(5 \mathrm{c})$ were changed from that of at OCV. The topography of MCMB particles at $1.5 \mathrm{~V}$ was raised about $140 \mathrm{~nm}$. At the potential of graphite electrode was $0.05 \mathrm{~V}, \mathrm{MCMB}$ particles grew about $0.8 \sim 4.0$ $\mu \mathrm{m}$ in length and $300 \mathrm{~nm}$ in height. After these large expansions of MCMB particles had occurred in the first cathodic polarization, the morphological change of MCMB was small in the anodic polarization, even at $1.0 \mathrm{~V}$, at which potential lithium de-intercalation would be finished.

The morphological changes of graphite electrode surface over $1.0 \mathrm{~V}$ were reported by the in situ AFM or STM studies $^{14-17,21)}$. Hirasawa reported that film deposition along graphite step edges was observed below $2 \mathrm{~V}$ vs. $\mathrm{Li} / \mathrm{Li}^{+}$in $\mathrm{LiClO}_{4} / \mathrm{EC}_{+}+\mathrm{EMC}^{14)}$. Chu also reported that surface species appeared on graphite steps or edge surfaces below $1.6 \mathrm{~V}$ vs. $\mathrm{Li}^{2} \mathrm{Li}^{+}$in $\mathrm{LiClO}_{4} / \mathrm{EC}+\mathrm{DMC}$, and at about $2.0 \mathrm{~V}$ in $\mathrm{LiPF}_{6} / \mathrm{EC}+\mathrm{DMCC}^{21}$. On the other hand, Inaba reported that a hill-like structure on graphite surface due to the intercalation of solvated $\mathrm{Li}^{+}$ion into graphite was observed at $1.1 \mathrm{~V}$ in $\mathrm{LiClO}_{4} / \mathrm{EC}+\mathrm{DEC}$ and $\mathrm{EC}+\mathrm{DME}^{16,17}$. Because they used the basal plane of highly ordered pyrolytic graphite(HOPG), the morphological changes occurred at the step edges and reported morphological changes were relatively small. But we observed the surface

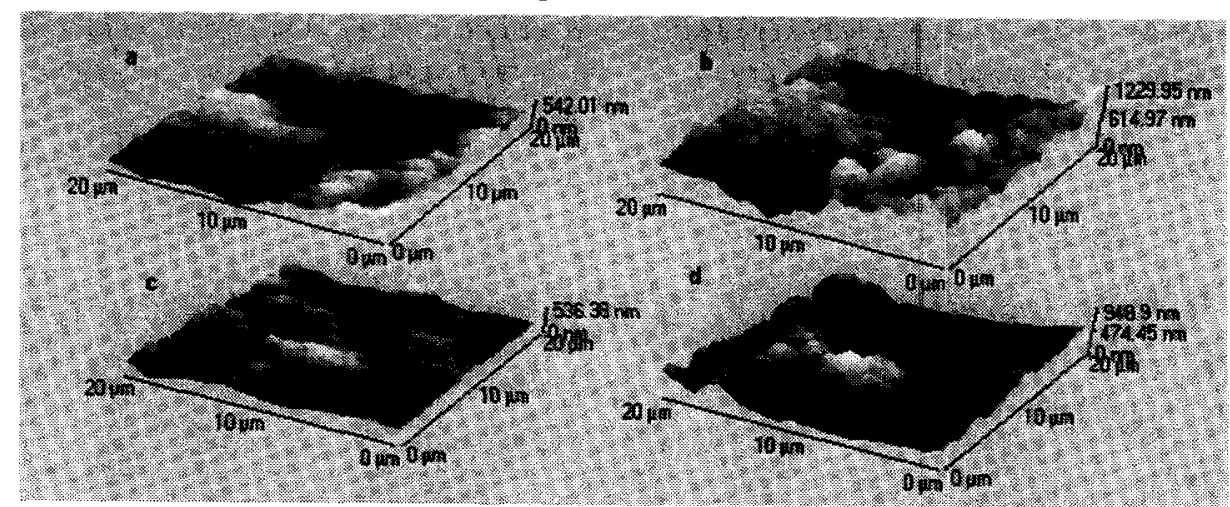

Fig. 4 AFM images $(20 \times 20 \mu \mathrm{m})$ of graphite electrode at various conditions. $\mathrm{a}, \mathrm{b}$; in $1 \mathrm{~mol} / \mathrm{dm}^{3} \mathrm{LiPF}_{6} / \mathrm{EC}+\mathrm{DEC}, \mathrm{c}, \mathrm{d}$; in $1 \mathrm{~mol} / \mathrm{dm}^{3} \mathrm{LiPF}_{6} / \mathrm{EC}+\mathrm{EMC}, \mathrm{a}, \mathrm{c}$; at OCV, b,d; at $0.05 \mathrm{~V}$ vs. Li/Li'.

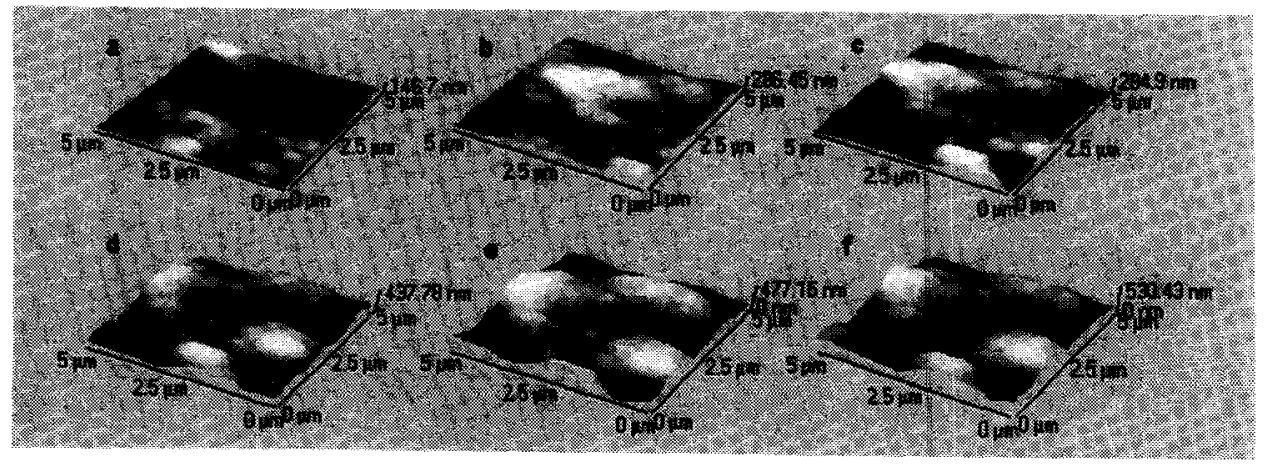

Fig. 5 AFM images $(5 \times 5 \mu \mathrm{m})$ of graphite electrode at various potentials in $1 \mathrm{~mol} / \mathrm{dm}^{3}$ LiPF $6 / E C+D E C$. a; OCV, b; 1.5V, c; 1.0V, d; 0.05V, e; 1.0V, f; 0.05V vs. Li/Lit. 
of MCMB particles which was mostly consisted of edge planes, so that our results of morphological changes were larger than other studies. We think these AFM images were obtained clearly, so that they were not affected by the soft depositions, such as binder or reduction products of solvents. Therefore, these results seem to clearly prove that the assumption for the intercalation which solvated $\mathrm{Li}^{+}$ ions intercalate with solvents into graphite layers and the decomposition of ternary graphite intercalation compounds (GICs)-Li(solv)yCn which results drastic expansion of the graphite matrix $(150 \sim 200 \%)^{22,23)}$. We think small amount of solvated $\mathrm{Li}^{+}$ion were doped into graphite layers and the decomposition of ternary compounds resulted the expansion of edge parts at $1.5 \mathrm{~V}$ vs. $\mathrm{Li} / \mathrm{Li}^{+}$.

Figure 6 shows the line-analysis of AFM images of graphite electrode in $\mathrm{LiPF}_{6} / \mathrm{EC}+\mathrm{DEC}$ at various condition for the analysis in detail. The center figures in Fig. 6 are the cross sections of the AFM images(left side) and the triangles in figures mark the same position. It was observed that several graphite particles expanded $90 \mathrm{~nm}$ in height and $80 \mathrm{~nm}$ in length at $1.0 \mathrm{~V} \mathrm{vs.} \mathrm{Li} / \mathrm{Li}^{+}(6 \mathrm{~b})$, and $230 \mathrm{~nm}$ in height and $410 \mathrm{~nm}$ in length at $0.05 \mathrm{~V}(6 \mathrm{c})$ from the OCV state(6a). The topography of expanded particles remained by the next anodic polarization to $1.0 \mathrm{~V}(6 \mathrm{~d})$.
Because MCMB particle is not a single crystal, we can not precisely estimate the expansion due to the intercalation. The expansion of particles was 4.5 times in height and 1.5 times in length from OCV state.

Next, we investigated the interfacial reaction of graphite electrodes and the decomposition products of (GICs)$\mathrm{Li}\left(\right.$ solv)yCn in $\mathrm{LiPF}_{6} / \mathrm{EC}+\mathrm{DEC}$ and in $\mathrm{LiPF}_{6} / \mathrm{EC}+\mathrm{EMC}$ by in situ FTIR spectroscopy.

Figure 7 shows IRAS spectra of $1 \mathrm{~mol} / \mathrm{dm}^{3} \mathrm{LiPF}_{6} / \mathrm{EC}+$ $\mathrm{DEC}$ at various potentials in the first cathodic polarization. Each spectrum is obtained by the interferogram of one before as a reference, that is, the spectrum $7 \mathrm{a}$ at $2.0 \mathrm{~V}$ vs. $\mathrm{Li} / \mathrm{Li}^{+}$is obtained by the interferogram at $\mathrm{OCV}$ as a reference, and the spectrum $7 \mathrm{~b}$ is obtained by the interferogram of $7 \mathrm{a}$ as a reference, respectively. Relatively large changes of the spectra were observed at $0.5 \mathrm{~V}(7 \mathrm{~d})$ and $0 \mathrm{~V}(7 \mathrm{e})$, and increasing peaks were observed at $1790(\mathrm{EC}, \mathrm{v}$ $\mathrm{C}=0), 1717\left(\mathrm{U}_{\mathrm{C}=\mathrm{O}}\right), 1114,1034,986,934$ and $898 \mathrm{~cm}^{-1}$. The major increasing peak in $7 \mathrm{e}$ was observed at $934 \mathrm{~cm}^{-1}$, which seemed to be ascribed to the C-C stretching vibrations of ether-compounds. The $1717 \mathrm{~cm}^{-1}$ peak $\left(\mathrm{U}_{\mathrm{C}}=0\right)$ was ascribed to lithium alkylcarbonate or ester-compound, but the other increased peaks would be ascribed to ethercompounds.

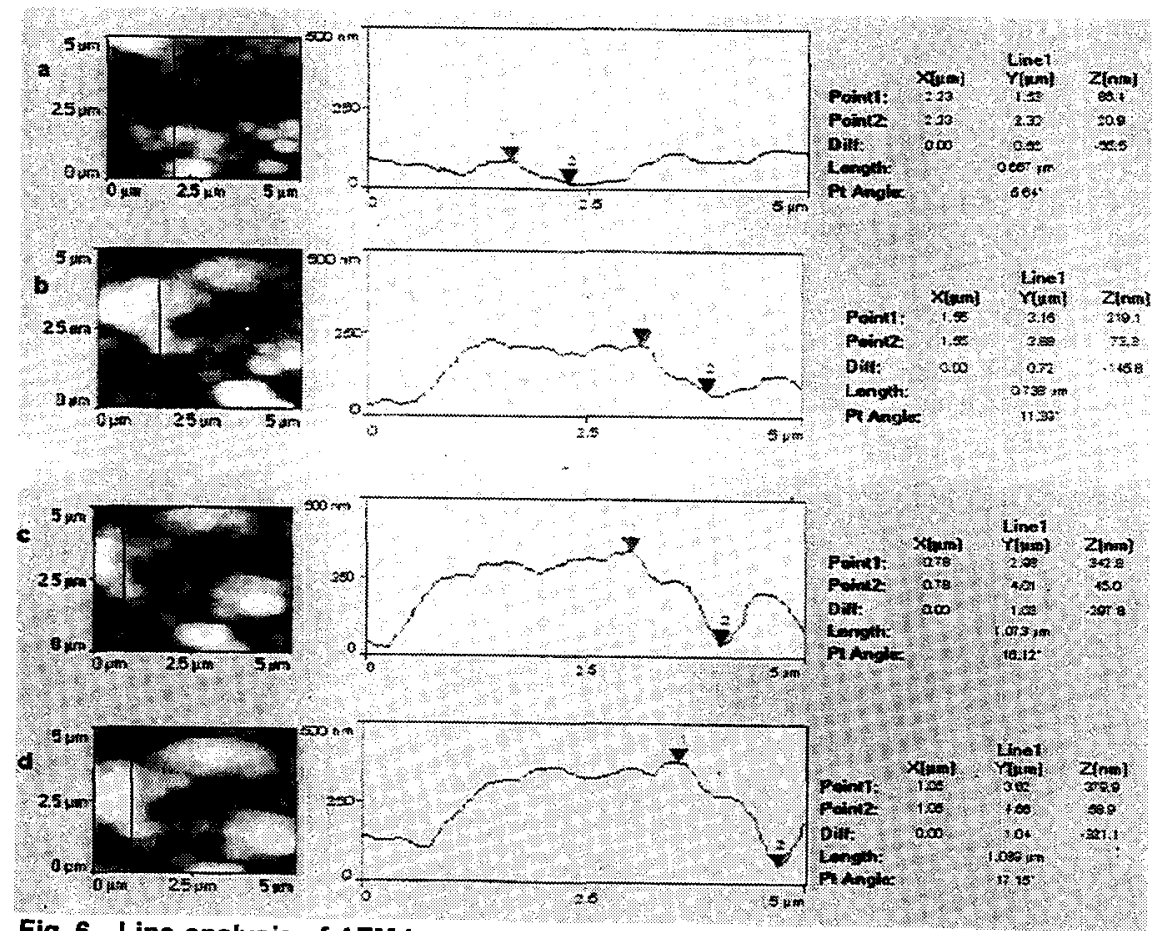

Fig. 6 Line-analysis of AFM images of the porlarized graphite electrode at various potentials in $1 \mathrm{~mol} / \mathrm{dm}^{3} \mathrm{LiPF}_{6} / \mathrm{EC}+\mathrm{DEC}$. a; OCV, b; $1.0 \mathrm{~V}, \mathrm{c} ; 0.05 \mathrm{~V}, \mathrm{~d} ; 1.0 \mathrm{~V} \mathrm{vs}$. Li/Li 


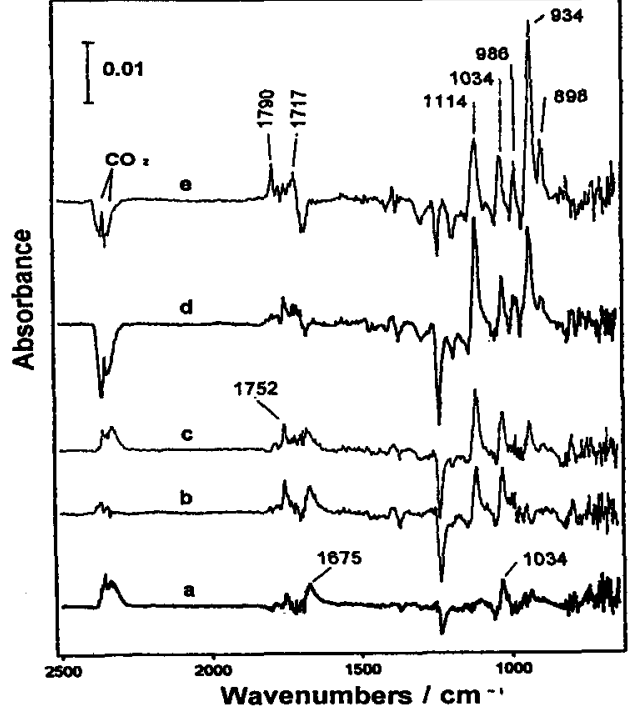

Fig. 7 IRAS spectra of $1 \mathrm{~mol} / \mathrm{dm}^{3} \mathrm{LIPF}_{\mathrm{d}} \mathrm{EC}+\mathrm{DEC}$ at various potentials in the first cathodic polarization on graphite electrode. a; 2.0V, b; 1.5V, c; 1.0V, d; 0.5V, e; OV vs. Li/Li'.

The IRAS spectra of $1 \mathrm{~mol} / \mathrm{dm}^{3} \mathrm{LiPF}_{6} / \mathrm{EC}+\mathrm{EMC}$, as the same in Fig.7, are shown in Fig.8. Some changes of the spectra were appeared from $2.0 \mathrm{~V}$ vs. $\mathrm{Li}^{2} \mathrm{Li}^{+}(8 \mathrm{a})$, the peaks at $1680(\mathrm{UC}=0), 1029$ and $950 \mathrm{~cm}^{-1}$ (Uc-C) might be ascribed to lithium alkylcarbonates, such as $\left(\mathrm{CH}_{2} \mathrm{OCO}_{2} \mathrm{Li}\right)_{2}$ reported before ${ }^{1-8)}$. The major increasing peaks in 8e(at OV) were observed at 950 and $915 \mathrm{~cm}^{-1}$, which seemed to relate to the $\mathrm{C}-\mathrm{C}$ stretching vibrations of ether-compounds.

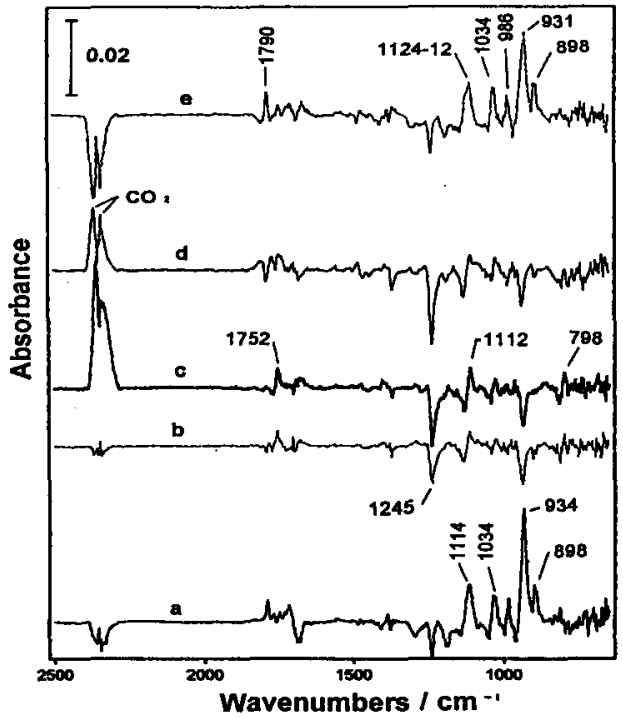

Fig. 9 IRAS spectra of $1 \mathrm{~mol}^{\mathrm{d} \mathrm{dm}^{3}} \mathrm{LIPF}_{\mathrm{G}} / \mathrm{EC}+\mathrm{DEC}$ at various potentials on graphite electrode. a; OV, b; $0.5 \mathrm{~V}, \mathrm{c} ; 1.0 \mathrm{~V}$, d; 0.5V, e; oV vs. Li/LI+.

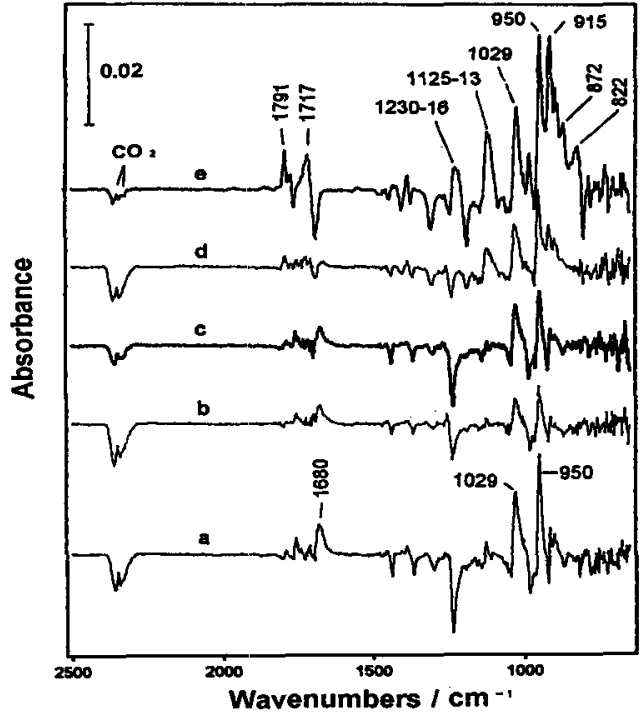

FIg. 8 IRAS spectra of $1 \mathrm{~mol} / \mathrm{dm}^{3}$ LIPF $_{6} / E C+E M C$ at various potentlals in the first cathodic polarization on graphite electrode. a; 2.0V, b; $1.5 \mathrm{~V}, \mathrm{c} ; 1.0 \mathrm{~V}, \mathrm{~d} ; 0.5 \mathrm{~V}, \mathrm{e} ; 0 \mathrm{~V} \mathrm{vs}$. LI/LI+.

The other peaks, except 1791 and $1717 \mathrm{~cm}^{-1}\left(\mathrm{UC}_{\mathrm{C}}=0\right)$ peaks, also seemed to be ascribed to ether-compounds.

Figure 9 shows IRAS spectra of $1 \mathrm{~mol} / \mathrm{dm}^{3} \mathrm{LiPF}_{6} / \mathrm{EC}+$ $\mathrm{DEC}$ at varicus potentials after the first cathodic polarization. The spectrum $9 b(a t) 0.5 \mathrm{~V}$ vs. $\mathrm{Li}^{2} / \mathrm{Li}^{\dagger}$ ) showed the decreasing peaks around $1245 \mathrm{~cm}^{-1}$ (Uc.o.c) and at $934 \mathrm{~cm}^{-1}($ vc-c) which was increased at $0 \mathrm{~V}$. The spectra $9 \mathrm{c}($ at $1.0 \mathrm{~V})$ and $9 \mathrm{~d}($ at $0.5 \mathrm{~V})$ showed the doublet peaks of $\mathrm{CO}_{2}(2360$

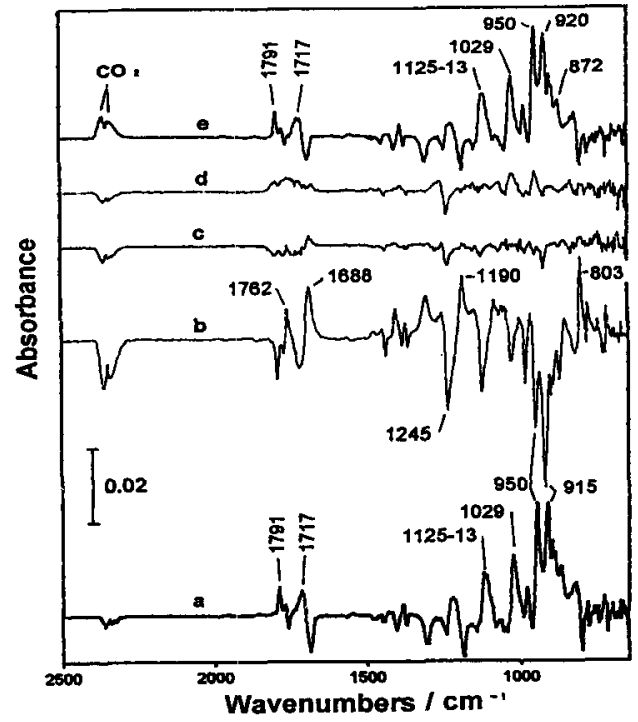

Fig. 10 IRAS spectra of $1 \mathrm{~mol} / \mathrm{dm}^{3}$ LIPF $6 / E C+E M C$ at various potentials on graphite electrode. a; $0 \mathrm{~V}, \mathrm{~b} ; 0.5 \mathrm{~V}, \mathrm{c} ; 1.0 \mathrm{~V}, \mathrm{~d}$; $0.5 \mathrm{~V}$, 0; OV Vs. LiLit. 
and $2340 \mathrm{~cm}^{-1}$ ) were increased very much. This increase of $\mathrm{CO}_{2}$ would be corresponding to the decomposition of solvents or lithium alkylcarbonates, by taking account of insufficient airtightness of the test cell. The spectrum 9e obtained at $\mathrm{OV}$ in the second polarization showed the almost same spectrum pattern as 9a.

The IRAS spectra of $1 \mathrm{~mol} / \mathrm{dm}^{3} \mathrm{LiPF}_{6} / \mathrm{EC}+\mathrm{EMC}$, as the same in Fig.9, are shown in Fig.10. The spectrum 10b(at $0.5 \mathrm{~V}$ vs. $\left.\mathrm{Li}^{2} / \mathrm{Li}^{+}\right)$was looked like the reverse form of the spectrum $10 \mathrm{a}(a \mathrm{at} 0 \mathrm{~V})$, precisely the peaks increased at $0 \mathrm{~V}$, such as $1791,1717,950,915 \mathrm{~cm}^{-1}$ and around $1120 \mathrm{~cm}^{-1}$, were decreased at $0.5 \mathrm{~V}$, and the peaks decreased at $0 \mathrm{~V}$, such as $1762,1688,1190$ and $803 \mathrm{~cm}^{-1}$, were increased at $0.5 \mathrm{~V}$. This result indicates that reduction products of solvents in the cathodic polarization were disappeared by the anodic polarization. The increasing of the peaks of $\mathrm{CO}_{2}$ in the spectrum 10e means the irreversible decomposition of solvents. Therefore, it seemed that the irreversible and reversible reactions exist in the interfacial reaction in $\mathrm{LiPF}_{6} / \mathrm{EC}+\mathrm{EMC}$.

Figure 11 compares DMFTIR spectra of $1 \mathrm{~mol} / \mathrm{dm}^{3}$ $\mathrm{LiPF}_{6} / \mathrm{EC}+\mathrm{DEC}(\mathrm{a})$ and $\mathrm{LiPF}_{6} / \mathrm{EC}+\mathrm{EMC}(\mathrm{b})$ at $\mathrm{OV}$ vs. $\mathrm{Li} / \mathrm{Li}^{+}$, and the subtractive spectra (c, d) of at $O \mathrm{~V}$ and at OCV. The DMFTIR spectrum at OV(Fig. 11a) showed that the dominant species at the graphite surface was lithium alkylcarbonate $\left(\mathrm{ROCO}_{2} \mathrm{Li}\right)$ which had a major peak around $1692 \mathrm{~cm}^{-1}$. Verily, the subtractive spectrum of $\mathrm{LiPF}_{6} / \mathrm{EC}+\mathrm{DEC}$ (Fig. 11c) showed the major increasing peak at $1696 \mathrm{~cm}^{-1}\left(\mathrm{UC}_{\mathrm{C}=0}\right)$ and the other peaks at $1045\left(\mathrm{UC}_{\mathrm{C}}\right)$ ), 953(UC-C) and $813 \mathrm{~cm}^{-1}$, which were ascribe to $\mathrm{ROCO}_{2} \mathrm{Li}$. We think this $\mathrm{ROCO}_{2} \mathrm{Li}$ is another reduction product of $\mathrm{EC}$, although Aurbach reported that $\left(\mathrm{CH}_{2} \mathrm{OCO}_{2} \mathrm{Li}\right)_{2}$ is the major reduction product of $\mathrm{EC}$, having peaks around 1650 ( $\left.v_{C}=0\right), 1300\left(v_{C}=0\right), 1080\left(v_{C}-0\right)$, and $830 \mathrm{~cm}^{-1}\left(\delta_{\mathrm{OCO}_{2}}\right)$. On the other hand, the spectra of $11 \mathrm{~b}$ and $11 \mathrm{~d}$ in $\mathrm{LiPF}_{6} / \mathrm{EC}+\mathrm{EMC}$ showed small changes after cathodic polarization. The spectrum 11d showed that increasing peaks at around $1700 \mathrm{~cm}^{-1}\left(\mathrm{uc}_{\mathrm{C}}-0\right), 1158,1070\left(\mathrm{vC}_{\mathrm{C}} \mathrm{O}\right)$ and $817 \mathrm{~cm}^{-1}$, and these peaks seemed to be ascribed to $\mathrm{ROCO} 2 \mathrm{Li}$. Although the major products in cathodic polarization were seemed to ether-compounds in IRAS spectra(Fig.7 10), the peaks around $910 \sim 950 \mathrm{~cm}^{-1}$ of ethercompounds (except the peak at $953 \mathrm{~cm}^{-1}$ in 11c) were not clearly observed in DMFTIR spectra at $0 \mathrm{~V}$. We think ether-compounds are soluble in electrolytes and not precipitated at electrodes, thus the dominant reduction products at graphite surface are lithium alkylcarbonates $\left(\mathrm{ROCO}_{2} \mathrm{Li}\right)$ in both systems. The amount of precipitated $\mathrm{ROCO}_{2} \mathrm{Li}$ on graphite surface was much higher in EC+DEC than that of in EC+EMC, by a comparison of $11 \mathrm{a}$ and $11 \mathrm{~b}$, precisely the absorbance of the peak $(1692$

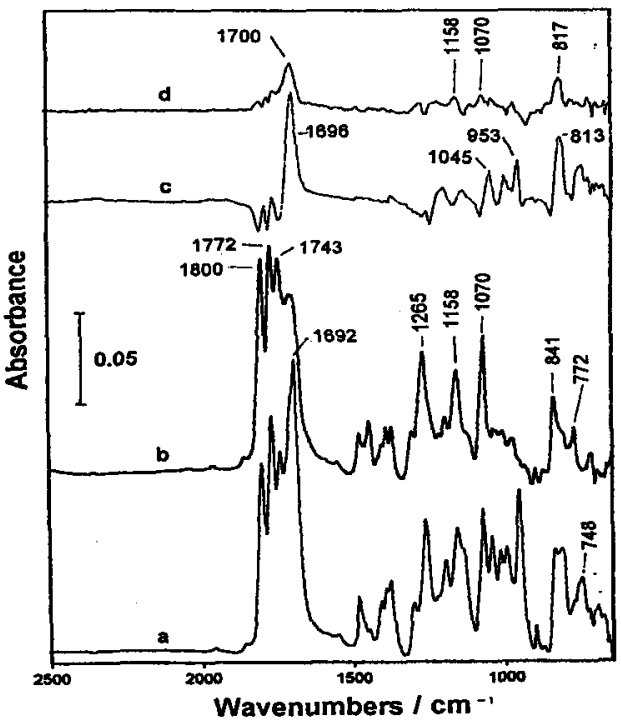

Fig. 11 DMFTIR spectra of LiPF $6 / E C+D E C(a)$ and LIPF $8 / E C$ $+E M C(b)$ at $\mathrm{OV}$ vs. $\mathrm{Li} / \mathrm{Li}^{+}$, and subtractive spectra of at $\mathrm{OCV}$ and at $O V$. a, c; LIPF $8 / E C+D E C, b, d ; L I P F / E C+E M C$, c, d; subtractive spectrum.

$\mathrm{cm}^{-1}$ ) was increased much higher than that of the solvents in EC+DEC.

In LiPF 6 /EC+DEC system, DMFTIR spectra showed the dominant surface product at graphite electrode was $\mathrm{ROCO} 2 \mathrm{Li}$ having a major peak around $1696 \mathrm{~cm}^{-1}$ after cathodic polarization(at 0V). The IRAS spectra(Fig.7 and 9) showed the major soluble products in the cathodic polarization were ether-compounds having a major peak around $930 \mathrm{~cm}^{-1}$ and the other peaks around 1120,1034 , 986 and $898 \mathrm{~cm}^{-1}$. The amount of $\mathrm{CO}_{2}$ (the peaks at 2360 and $\left.2340 \mathrm{~cm}^{-1}\right)$ in the electrolyte was increased in the second cathodic polarization, and it indicated the decomposition of solvents. These results of FTIR spectroscopy revealed the instability of DEC, that is, DEC was easy to reduce and reduction products of DEC were soluble in electrolyte and not precipitated at the graphite surface. Thereby it seemed that the passivation of the graphite surface was insufficient for the reduction of solvents in EC+DEC.

On the other hand in $\mathrm{LiPF}_{6} / \mathrm{EC}+\mathrm{EMC}$ system, DMFTIR spectra showed the dominant surface species at graphite electrode were EC and EMC even after cathodic polarization. Although $\mathrm{ROCO}_{2} \mathrm{Li}$ having the major peaks around $1700 \mathrm{~cm}^{-1}$ was increased, the changes of surface species by the polarization was small. The IRAS spectra (Fig. 8 and 10) showed reduction products were ethercompounds, which had the major peaks at 950 and 915 $\mathrm{cm}^{-1}\left(U_{C}-C_{)}\right)$and the other peaks around $1120,1030,872$ and $822 \mathrm{~cm}^{-1}$. But these peaks ascribed to ether-compounds 
were decreased, and the peaks which were decreased at $0 \mathrm{~V}$ were increased by anodic polarization. Therefore, we think that these peaks may be corresponding to solvation of lithium ion or decomposition of solvents, that is the amount of highly oriented solvent or decomposed solvent increased after lithium intercalation (at OV), and the amount of this decreased after de-intercalation (at IV).

\section{CONCLUSION}

The present study proved the two methods, FTIR spectroscopy and AFM observation, were the effective approaches for in situ analysis even at graphite composite electrodes which were not flat and smooth surface. The morphological changes of graphite electrodes were observed even at $1.5 \mathrm{~V}$ vs. $\mathrm{Li} / \mathrm{Li}^{+}$at the first cathodic polarization both in $\mathrm{LiPF}_{6} / \mathrm{EC}+\mathrm{DEC}$ and in $\mathrm{LiPF}_{6} / \mathrm{EC}+$ EMC. A larger expansion of graphite particles at $0.05 \mathrm{~V}$, such as 4.5 times in height and 1.5 times in length, was observed in EC+DEC. After this large expansion of graphite had occurred, the morphological changes was small by anodic or cathodic polarizations. The results of AFM observation were consisted with the assumption of solvated lithium intercalation by Besenhard ${ }^{21)}$ in the followings;

1) The morphological changes start over $1 \mathrm{~V}$ vs. $\mathrm{Li} / \mathrm{Li}^{+}$.

2) Very large expansion of graphite due to the decomposition of the ternary graphite-intercalation compounds (GICs)-Li(solv)yCn was observed only at first cathodic polarization.

The DMFTIR spectroscopy, the effective detection for the interfacial reactions, showed that both $\mathrm{EC}+\mathrm{DEC}$ solution and EC+EMC solution containing $1 \mathrm{~mol} / \mathrm{dm}^{3}$ $\mathrm{LiPF}_{6}$ were unstable on graphite electrodes even at open circuit state. After cathodic polarization, $\mathrm{ROCO}_{2} \mathrm{Li}$ having a peak at $1696 \mathrm{~cm}^{-1}$ was observed as the dominant surface species in EC+DEC. This result reveals that the surface chemistry of graphite and the degree of passivation are different in EC+EMC from in EC+DEC. The IRAS spectra showed that major soluble products of solvents were similar ether-compounds which have the major peak at $930 \mathrm{~cm}^{-1}$ in EC+DEC, and the peaks at 950 and $920 \mathrm{~cm}^{-1}$ in EC+EMC. But the difference of DEC and EMC was appeared at the anodic polarization, as shown in Fig. 9 and 10. This different behavior would be caused by the interfacial reactions of graphite electrodes. We think the surface of graphite was covered by insoluble $\mathrm{ROCO}_{2} \mathrm{Li}$ and these insoluble products were more tightly and passivated in EC+EMC than in EC+DEC. The film formation due to the decomposition of (GICs)-Li(solv)yCn was not clearly observed both in DMFTIR and IRAS spectroscopy.
The authors express their sincere thanks to the New Energy and Industrial Technology Development Organization for their support of this work.

\section{REFERENCES}

1) D. Aurbach, M.L. Daroux, P.W. Faguy, and E.B. Yeager, J. Electrochem. Soc., 134, 1611 (1987).

2) D. Aurbach, and O.Y. Chusid, J. Electrochem. Soc., 140, L155 (1993).

3) D. Aurbach, Y. Ein-Ely, and A. Zaban, J. Electrochem. Soc., 141, L1 (1994).

4) D. Aurbach, O.Y. Chusid, Y. Carmeli, M. Babai and Y. Ein-Eli, J. Power Sources, 43, 47 (1993).

5) D. Aurbach, A. Zatan, A. Schechter, Y. Ein-Eli, E.Zinigrad, and B. Markovsky, J. Electrochem. Soc., 142, 2873 (1995).

6) D. Aurbach, Y. Ein-Eli, B. Markovsky, A. Zaban, S.Luski, Y. Carmeli and H. Yamin, J. Electrochem. Soc., 142, 2882 (1995).

7) D. Aurbach, B. Markovsky, A. Shechter, Y. Ein-Eli and H. Cohen, J. Electrochem. Soc., 143, 3809 (1996).

8) Y. Ein-Eli, S.R. Thomas, V. Koch, D. Aurbach, B. Markovsky and A. Schechter, J. Electrochem. Soc., 143, L273 (1996).

9) K. Kanamura, H. Takezawa, S. Shiraishi and Z. Takehara, J. Electrochem. Soc., 144, 1900 (1997).

10) E.S. Takeuchi, H. Gan, M. Palazzo, R.A. Leising and S.M. Davis, J. Electrochem. Soc., 144, 1944 (1997).

11) K. Morigaki, N. Kabuto, K. Yoshino, and A. Ohta, 35th Battery Symposium, Extended Abstract, 83 (1994).

12) K. Morigaki, N. Kabuto, K. Yoshino and A. Ohta, Power Sources 15 (Eds. A. Attewell and T. Keily), Int. Power Sources Symposium Committee, 267 (1995).

13) K. Morigaki, T. Fujii, and A. Ohta, 37th Battery Symposium, Extended Abstract, 167 (1996).

14) K.A. Hirasawa, T. Sato, H. Asahina, S. Yamaguchi and S. Mori, J. Electrochem. Soc., 144, L81 (1997).

15) S. Yamaguchi, K.A.Hirasawa, T. Sato, H. Asahina and S. Mori, 2nd Korean-Japan Joint Seminar on Advanced Batteries, Extended Abstract, 153 (1997).

16) M. Inaba, Z. Siroma, A. Funabiki, Z. Ogumi, T. Abe, Y. Mizutani and M. Asano, Langmuir, 12, 1535 (1996).

17) Z. Ogumi, Z. Siroma, Y. Kawatate, A. Funabiki, T. Abe, and M. Inaba, 2nd Korcan-Japan Joint Seminar on Advanced Batteries, Extended Abstract, 163 (1997).

18) M. Tatsumi, FTIR no Kiso to Jissai (2nd.Ed.). Tokyo kagaku doujin, Tokyo, pl 12 (1994).

19) K. Kanamura, H. Tamura, and $Z$. Takehara, $J$. Electroanal. Chem., 333, 127 (1992). 
20) K. Kanamura, S. Shiraishi, H. Tamura, and Z. Takehara, J. Electrochem. Soc., 141, 2379 (1994).

21) A.C. Chu, J.Y. Josefowicz, and G.C. Farrington, J. Electrochem. Soc., 144, 4161 (1997).
22) J.O. Besenhard, M. Winter, J. Yang, and W. Biberacher, J. Power Source, 54, 228 (1995).

23) M. Winter, P. Novak, and A. Monnier, J. Electrochem. Soc., 145, 428 (1998). 